\title{
Perlindungan Hukum Bagi Konsumen Pengguna Kartu Debit Terkait Pembebanan Biaya Tambahan Pada Mesin EDC (Electronic Data Captured)
}

\author{
Lana Almira Luthfiana Istiqlal dan Dian Purnama Anugerah \\ lanally09@gmail.com \\ Universitas Airlangga
}

\begin{abstract}
Keywords: $\quad$ Abstract
Additional Fee; This Journal entitled "Legal Protection For Consumers of Debit Card Users According EDC (Electronic to Additional Fee on the EDC (Electronic Data Captured) Machine", this study used a Data Capture) normative juridical method, a statutory approach, and a conceptual approach. This thesis Machine;

Consumer

Protection Law. has 2 (two) main problems, which is (1) additional fee charge on EDC (Electronic Data Captured) machine to consumers of debit cards break the consumer rights under consumer protection laws, (2) action that can be made by consumers who use debit cards to losses arising after making transactions at the EDC (Electronic Data Captured) machine. From legal research can be concuded on first main problem there are consumer rights under consumer protection laws which is violated, according to Article 8 Paragraph (2) Indonesia Bank Regulation Number 11/11/PBI/2009 and Circural Letter Bank Indonesia Number 11/10/DASP/2009 merchant should not be charged additional fee to consumers, and the second main problem is legal remedies which consumers can do if charge additional fee, consumers can make dispute resolution through consumer complaint service in the bank and alternative institutions of Indonesian banking dispute settlement.
\end{abstract}

Kata Kunci: $\quad$ Abstrak

Biaya Tambahan; Artikel ini berjudul “Perlindungan Hukum Bagi Konsumen Pengguna Kartu Debit Mesin EDC (Electronic Data Captured); Hukum Perlindungan Konsumen. Tekait Pembebanan Biaya Tambahan Pada Mesin EDC (Electronic Data Captured)", metode penulisan yang digunakan bersifat normatif, dengan menggunakan pendekatan undang-undang dan pendekatan konseptual. Rumusan masalah yang diangkat dalam penulisan ini adalah: (1) Apakah pembebanan biaya transaksi pada mesin EDC (Electronic Data Captured) kepada konsumen pengguna kartu debit melanggar hak konsumen di dalam Undang-Undang Nomor8Tahun1999, (2) Upaya yang dapat dilakukan konsumen pengguna kartu debit akibat adanya kerugian yang timbul setelah melakukan transaksi pembayaran di mesin EDC (Electronic Data Captured). Dari penelitian hukum yang telah dilakukan dapat disimpulkan pada rumusan masalah pertama terdapat hak-hak konsumen pada UndangUndang Perlindungan Konsumen yang dilanggar jika konsumen dibebankan biaya tambahan oleh merchant, menurut Pasal 8 ayat (2) Peraturan Bank Indonesia Nomor 11/11/PBI/2009, dan Surat Edaran Nomor 11/10/DASP/2009 merchant tidak diperbolehkan untuk mengalihkan beban biaya tambahan kepada konsumen, sedangkan untuk rumusan masalah yang kedua terkait upaya hukum yang dapat dilakukan konsumen jika dikenakan biaya tambahan oleh merchant yaitu dapat melakukan pengaduan nasabah melalui layanan pengaduan nasabah yang telah disediakan oleh bank, jika tidak berhasil dapat mengajukan penyelesaian sengketa ke Lembaga Alternatif Penyelesaian Sengketa yang sudah terdaftar di Otoritas Jasa Keuangan yaitu Lembaga Alternatif Penyelesaian Sengketa Perbankan Indonesia (LAPSPI). 


\section{Pendahuluan}

Perbankan merupakan suatu lembaga keuangan di Indonesia yang perkembangannya pesat dan memiliki nilai strategis untuk pertumbuhan ekonomi khususnya di Indonesia. Transaksi perbankan yang paling utama adalah menghimpun dana (funding) dan menyalurkan dana (lending) selain itu transaksi perbankan lainnya yaitu memberikan jasa-jasa perbankan (service). ${ }^{1}$ Jasa menurut Pasal 1 Angka 5 Undang-Undang Nomor 8 Tahun 1999 tentang Perlindungan Konsumen yaitu setiap layanan yang berbentuk pekerjaan atau prestasi yang disediakan bagi masyarakat untuk dimanfaatkan oleh konsumen. Pengertian "disediakan kepada masyarakat" menunjukan bahwa jasa tersebut harus ditawarkan kepada masyarakat. ${ }^{2}$ Semakin lengkap jasa bank yang diberikan maka semakin baik artinya nasabah bank tersebut jika hendak melakukan suatu transaksi perbankan hanya cukup di satu bank saja tidak perlu ke bank-bank lain. ${ }^{3}$ Dalam menjalankan kegiatan usahanya terdapat hubungan hukum yang terjadi antara bank dan nasabah yaitu didasarkan kepada hubungan kepercayaan (fiduciary relationship). Kepercayaan yang dibangun oleh nasabah dibangun dengan cara menyimpan dananya di bank dalam suatu portofolio dan dikelola dengan aman dan jujur, sehingga sewaktu-waktu nasabah membutuhkan dana tersebut bank mampu menyediakan. ${ }^{4}$

Dalam upaya mendapatkan kepercayaan masyarakat pihak perbankan harus mengeluarkan produk bank yang memenuhi kebutuhan masyarakat dan mengikuti perkembangan zaman. Sampai saat ini jasa perbankan yang rata-rata masyarakat Indonesia miliki adalah Bank Card atau uang plastik yang dikeluarkan oleh bank, contoh dari Bank Card adalah kartu debit. Kartu debit merupakan salah satu jenis alat pembayaran yang dikeluarkan oleh bank untuk melakukan transaksi non tunai atau pengganti uang tunai, dapat juga digunakan untuk

1 Trisadini P Usanti dan Abd Shomad, Hukum Perbankan (Kencana 2017).[1].

2 Andi Sri Rezky Wulandari dan Nurdiyana Tadjuddin, Hukum Perlindungan Konsumen (Mitra Wacana Media 2019).[21-22].

${ }^{3}$ Kasmir, Bank Dan Lembaga Keuangan Lainnya (Rajawali Press 2001).[145].

4 Shomad (n 1)., Op Cit.[20]. 
tarik tunai pada Mesin ATM (Automated Teller Machine). Pengertian kartu debit diatur dalam Pasal 1 angka 6 Peraturan Bank Indonesia Nomor 14/02/ PBI/ 2012 Tentang Perubahan Atas Peraturan Bank Indonesia Nomor 11/11/PBI/2009 tentang Penyelenggaraan Kegiatan Alat Pembayaran Dengan Menggunakan Kartu bahwa "Kartu Debet merupakan APMK yang dapat digunakan untuk melakukan pembayaran atas kewajiban yang timbul dari suatu kegiatan ekonomi, termasuk transaksi pembelanjaan, dimana kewajiban pemegang kartu dipenuhi seketika dengan mengurangi secara langsung simpanan pemegang kartu pada Bank atau Lembaga Selain Bank yang berwenang untuk menghimpun dana sesuai ketentuan perundang-undangan yang berlaku." Penggunaan kartu debit sendiri adalah seperti pembayaran tunai tanpa uang tunai dengan cara mendebet (mengurangi) rekening nasabah dan otomatis akan mengkredit (menambah) rekening merchant. ${ }^{5}$

Merchant atau pedagang merupakan pelaku usaha yang menerima transaksi pembayaran dari pengguna kartu debit, untuk melakukan transaksi pembayaran merchant membutuhkan mesin EDC (Electronic Data Captured). Cara perolehan mesin EDC (Electronic Data Captured) yaitu pihak merchant (pedagang) harus mengajukan ke bank. Karena mesin EDC (Electronic Data Captured) adalah sebuah jasa yang diberikan oleh bank kepada merchant, maka terdapat biaya tambahan yang diberikan bank kepada merchant atas jasa yang diperoleh, biaya tambahan tersebut biasa disebut dengan Merchant Discount Rate (MDR). Saat merchant melakukan permohonan pembukaan atas mesin EDC (Electronic Data Captured) kepada bank, pihak bank terlebih dahulu melampirkan persyaratan kepada merchant, salah satu syarat yang ada yaitu menyetujui Merchant Discount Rate yang sudah ditentukan oleh bank yang bersangkutan sebagai biaya tambahan dan langsung dibebankan ke merchant bukan ke konsumen, jika merchant menyetujui maka pihak bank akan melakukan proses lebih lanjut. ${ }^{6}$

5 Shinta Wahyu Hati, 'Analisa Faktor-Faktor Yang Turut Mempengaruhi Perilaku Nasabah Dalam Menggunakan Kartu Debit’ (2009) 4 Iqtishoduna.[2].

6 Wawancara dengan Customer Service Supervisor Bank Mandiri Kantor Cabang Universitas Airlangga, Surabaya, 13 November 2019. 
Bank Indonesia sendiri sebagai pihak yang mengeluarkan aturan mengenai biaya tambahan pada metode Electronic Data Captured secara langsung telah melarang para merchant untuk membebankan biaya tambahan kepada konsumen pengguna kartu debit. Hal tersebut dibuktikan pada Pasal 8 ayat (2) Peraturan Bank Indonesia Nomor 11/11/PBI/2009 bahwa "Acquirer wajib menghentikan kerja sama dengan Pedagang yang melakukan tindakan yang dapat merugikan", dan pada Surat Edaran Nomor 11/10/DASP/2009 Tentang Penyelenggaraan Kegiatan Alat Pembayaran Dengan Menggunakan Kartu yang menyatakan bahwa dalah hal Acquirer melakukan kerjasama dengan pedagang, Acquirer tersebut harus memastikan bahwa pedagang dilarang mengenakan biaya tambahan (surcharge) kepada pemegang kartu. Acquirer yang dimaksud adalah bank atau lembaga selain bank yang bekerjasama dengan pedagang (merchant). Tindakan yang merugikan yang dilakukan pedagang adalah tindakan yang sesuai pada penjelasan Pasal 8 ayat (2) Peraturan Bank Indonesia Nomor 14/2/PBI/2012 tentang Perubahan Atas Peraturan Bank Indonesia Nomor 11/11/PBI/ 2009 tentang Penyelenggaraan Kegiatan Alat Pembayaran Dengan Menggunakan Kartu yaitu “tindakan Pedagang yang merugikan Prinsipal, Penerbit, Acquirer dan/atau Pemegang Kartu, antara lain Pedagang diketahui telah melakukan kerjasama dengan pelaku kejahatan (fraudster), memproses penarikan/gesek tunai (cash withdrawal transaction) Kartu Kredit, atau memproses tambahan biaya transaksi (surcharge)."

Peraturan Bank Indonesia merupakan peraturan yang memiliki daya berlaku dalam hierarki peraturan-perundang-undangan, hal ini diatur di dalam Pasal 8 ayat (1) Undang-Undang Nomor 12 Tahun 2011 tentang Pembentukan Peraturan Perundang-Undangan yang menyatakan bahwa

"Jenis Peraturan Perundang-undangan selain sebagaimana dimaksud dalam Pasal 7 ayat (1) mencakup peraturan yang ditetapkan oleh Majelis Permusyawaratan Rakyat, Dewan Perwakilan Rakyat, Dewan Perwakilan Daerah, Mahkamah Agung, Mahkamah Konstitusi, Badan Pemeriksa Keuangan, Komisi Yudisial, Bank Indonesia, Menteri, badan, lembaga, atau komisi yang setingkat yang dibentuk dengan Undang-Undang atau Pemerintah atas perintah Undang-Undang, Dewan Perwakilan Rakyat Daerah Provinsi, Gubernur, Dewan Perwakilan Rakyat Daerah Kabupaten/ Kota, Bupati/Walikota, Kepala Desa atau yang setingkat." 
Dapat disimpulkan bahwa Peraturan Bank Indonesia termasuk peraturan yang bersifat memaksa (Dwingend Recht) yaitu peraturan-peraturan hukum yang tidak boleh disimpangi sehingga harus ditaati. Sehingga perjanjian pengajuan mesin EDC (Electronic Data Captured) antara merchant dan bank, perjanjian kartu debit antara konsumen dan bank mengacu ke Peraturan Bank Indonesia berdasarkan asas kebebasan berkontrak.

Dasar berlaku asas kebebasan berkontrak adalah Pasal 1338 BW, di dalam Pasal 1338 ayat (1) BW menyatakan bahwa semua kontrak (perjanjian) yang dibuat secara sah berlaku sebagai undang-undang bagi mereka yang membuatnya, maksud dari "semua" yaitu setiap orang dapat membuat perjanjian apa saja tidak terbatas pada jenis perjanjian yang diatur dalam BW dan perjanjian tersebut mengikat para pihak. Di dalam Pasal 1338 BW tersebut juga menggunakan istilah “yang dibuat secara sah" yang artinya apa yang disepakati para pihak berlaku sebagai undang-undang selama apa yang disepakati itu sah, tidak bertentangan dengan undang-undang, ketertiban umum, dan kesusilaan. ${ }^{7}$

Biaya Tambahan Bagi Pengguna Kartu Debit dan Pelanggan Hak Konsumen Dalam Undang-Undang Nomor 8 Tahun 1999 tentang Perlindungan Konsumen

Di dalam kasus pengenaan biaya tambahan oleh merchant kepada konsumen pengguna kartu debit terdapat beberapa hak konsumen pada Undang-Undang Perlindungan Konsumen yang dilanggar oleh merchant selaku pelaku usaha. Hal ini terjadi karena pihak merchant sebagai pelaku usaha tidak ingin dirugikan, sesuai dengan prinsip ekonomi yang diajarkan yaitu agar pelaku usaha mengeluarkan pengorbanan yang sekecil-kecilnya untuk meraih keuntungan yang sebesarbesarnya. Untuk mewujudkan prinsip tersebut para merchant melakukan berbagai cara agar dirinya tidak dirugikan. Hal tersebut bisa dibuktikan saat merchant membebankan biaya tambahan kepada konsumen pengguna kartu debit yaitu dengan tujuan agar merchant tidak dirugikan karena merchant harus membayar

7 Ghansam Anand, 'Prinsip Kebebasan Berkontrak Dalam Penyusunan Kontrak' [2011] Yuridika.[96]. 
Lana Almira: Perlindungan Hukum Bagi...

Merchant Discount Rate kepada bank.

Pertama, merchant selaku pelaku usaha telah melanggar Pasal 4 huruf b Undang-Undang Perlindungan Konsumen yaitu hak untuk mendapatkan nilai barang/jasa sesuai dengan nilai tukar yang diberikan, hak ini digunakan konsumen untuk melindungi dirinya dari kerugian akibat permainan harga yang tidak wajar yang dilakukan oleh merchant. ${ }^{8}$ Misalnya saja seharusnya konsumen hanya membayar barang sebesar Rp 100.000,00 namun merchant membebankan biaya tambahan sebesar 1\% sehingga menjadi Rp 101.000,00. Dalam hal ini konsumen pengguna kartu debit menjadi korban, konsumen dihadapkan pada kondisi take it or leave it, sehingga mau tidak mau konsumen harus tetap membayar sesuai dengan yang merchant tagihkan. Walaupun biaya tambahan terkadang menurut konsumen tidak memberatkan karena jumlahnya yang relatif kecil namun tetap saja hal tersebut tidak dibenarkan karena harga suatu barang atau jasa yang tertera berbeda dengan saat hendak di transaksikan.

Kedua, hak yang dilanggar adalah hak pada Pasal 4 huruf c UndangUndang Perlindungan Konsumen yaitu hak atas informasi yang benar, jelas, dan jujur, mengenai kondisi dan jaminan barang dan/atau jasa. Dalam hal ini terdapat merchant yang langsung membebankan biaya tambahan ke konsumen kartu debit tanpa adanya pemberitahuan terlebih dahulu. Namun tidak menutup kemungkinan juga merchant tersebut memberitahu konsumen adanya biaya tambahan, hal ini termasuk dalam penyalahgunaan keadaan konsumen atau misbruik van omstandigheden. Nieuwenhuis mengemukakan 4 syarat adanya penyalahguaan keadaan, yaitu keaadaan-keadaan istimewa (bijzondere omstandigheden), suatu hal yang nyata (kenbaarheid), penyalahgunaan (misbruik), hubungan kausal (casuaal verband). ${ }^{9}$ Penyalahgunaan (misbruik) yaitu salah satu pihak telah menyelesaikan perjanjian tersebut walaupun dia mengetahui atau seharusnya mengerti bahwa dia seharusnya tidak melakukannya. ${ }^{10}$ Keadaan

8 Andi Sri Rezky Wulandari dan Nurdiyana Tadjuddin (n 2)., Op Cit.[45].

9 Sutedjo Bomantoro, Implementasi Doktrin Penyalahgunaan Keadaan Dalam Perjanjian Dalam Praktek Peradilan Di Indonesia (Universitas Islam Indonesia 2004).[92].

10 ibid. 
seperti itu yang membuat konsumen mau tidak mau mengiyakan biaya tambahan yang diberikan merchant, menurut Pasal 1320 BW dapat disimpulkan sepakat yang dilakukan konsumen atas dasar penyalahgunaan keadaan bukan sepakat yang sah, sehingga tetap saja jika merchant memberitahu adanya biaya tambahan kepada konsumen tidak diperbolehkan oleh Peraturan Bank Indonesia dan dapat melanggar hak konsumen.

Ketiga, adalah hak pada Pasal 4 huruf g Undang-Undang Perlindungan Konsumen yaitu hak konsumen untuk diperlakukan dan dilayani secara jujur oleh merchant atau pelaku usaha. Namun dalam hal ini merchant sengaja membebankan biaya tambahan kepada konsumen pengguna kartu debit, bahkan terkadang ada merchant yang tidak memberitahu konsumen mengenai biaya tambahan, jelas perlakukan merchant tersebut telah melanggar Peraturan Bank Indonesia mengenai biaya tambahan. Hal semacam ini dapat merugikan konsumen itu sendiri, perlunya sikap sadar dan paham oleh konsumen akan hak untuk dilayani dan diperlakukan secara jujur.

Terakhir yang keempat, konsumen pengguna kartu debit yang merasa haknya dilanggar berhak menuntut hak konsumen pada Pasal 4 huruf h UndangUndang Perlindungan Konsumen yaitu hak untuk mendapat ganti kerugian apabila barang atau jasa tidak sesuai. Hak ini dimaksudkan untuk memulihkan keadaan yang telah menjadi rusak (tidak seimbang) akibat tidak terpenuhinya harapan konsumen, ganti kerugian ini bisa berupa materi maupun kerugian yang menyangkut diri konsumen. ${ }^{11}$ Pada umumnya ganti kerugian dapat melalui pengadilan maupun diluar pengadilan. Memberikan ganti rugi merupakan kewajiban pelaku usaha sesuai dalam Pasal 7 huruf g Undang-Undang Perlindungan Konsumen. Pemberian suatu ganti kerugian harus berdasarkan pada ketentuan perundang-undangan yang mengatur maupun perjanjian yang telah disepakati. Pasal 29 Peraturan Otoritas Jasa Keuangan Nomor 1/POJK.07/2013 juga mengatur mengenai ganti kerugian dalam hal ini pelaku usaha jasa keuangan

${ }^{11}$ Andi Sri Rezky Wulandari dan Nurdiyana Tadjuddin (n 2)., Op Cit.[44]. 
wajib memberi ganti kerugian kepada konsumen akibat kesalahan atau kelalaian pengurus, pegawai pelaku jasa keuangan dan/atau pihak ketiga yang bekerja untuk kepentingan pelaku usaha jasa keuangan.

Dapat dilihat dari penjelasan di atas bahwa membebankan biaya tambahan kepada konsumen pengguna kartu debit merupakan perlakuan yang dapat melanggar hak konsumen pada Undang-Undang Perlindungan Konsumen. Pemenuhan hak-hak konsumen akan melindungi konsumen dari berbagai aspek kerugian, hal ini dapat dilakukan oleh merchant sebagai pelaku usaha dan pemerintah sebagai pihak yang melakukan perlindungan konsumen. ${ }^{12}$

\section{Upaya Preventif dalam Pengenaan Biaya Tambahan pada Mesin Electronic Data Captured (EDC)}

Penegakan hukum tidak melulu dimaknai sebagai tindakan memaksa individu untuk dipatuhi, namun terdapat penegakan hukum yang bentuknya yaitu upaya untuk mencegah agar tidak terjadi pelanggaran hukum. Penegakan hukum preventif bisa dengan cara memberikan bekal pemahaman dan kesadaran bagi masyarakat. ${ }^{13}$

\section{Upaya Preventif dari Otoritas Jasa Keuangan}

Otoritas Jasa Keuangan sebagai lembaga yang berfungsi untuk menyelenggarakan pengaturan dan pengawasan di dalam sektor jasa keuangan termasuk perbankan memiliki tujuan diatur dalam Pasal 4 UndangUndang Nomor 21 Tahun 2011 tentang Otoritas Jasa Keuangan yang salah satu tujuannya adalah untuk melindungi kepentingan konsumen dan masyarakat. Selain itu Otoritas Jasa Keuangan berwenang melakukan edukasi, pelayanan pengaduan, sampai dengan pembelaan hukum terhadap konsumen yang diugikan oleh lembaga jasa keuangan. ${ }^{14}$

\footnotetext{
12 ibid.[47].

13 Victorianus M.H. Randa Puang, Hukum Pendirian Usaha Dan Perizinan (Deepublish 2015).[63].

${ }^{14}$ Agus Suwandono dan Deviana Yuanitasari, 'Kedudukan Lembaga Alternatif Penyelesaian Sengketa Sektor Jasa Keuangan Dalam Hukum Perlindungan Konsumen’ (2016) 1 Bina Mulia Hukum.[15].
} 
Dalam menghindari adanya keluhan dari nasabah, serta sebagai wujud perlindungan hukum bagi konsumen jasa perbankan Otoritas Jasa Keuangan di dalam Peraturan Otoritas Jasa Keuangan Nomor 1/POJK.07/2013 tentang Perlindungan Konsumen Sektor Jasa Keuangan di dalam Pasal 4 ayat (1) juga mewajibkan pelaku usaha jasa keuangan menyediakan dan menyampaikan informasi mengenai produk dan/atau layanan secara akurat, jujur, jelas, dan tidak menyesatkan kepada konsumen jasa perbankan. Yang dimaksud pelaku usaha jasa keuangan yaitu yang terdapat dalam Pasal 1 angka 1 Peraturan Otoritas Jasa Keuangan Nomor 1/POJK.07/2013 tentang Perlindungan Konsumen Sektor Jasa Keuangan adalah Bank Umum, Bank Perkreditan Rakyat, Perusahaan Efek, Penasihat Investasi, Bank Kustodian, Dana Pensiun, Perusahaan Asuransi, Perusahaan Reasuransi, Lembaga Pembiayaan, Perusahaan Gadai, dan Perusahaan Penjaminan, baik yang melaksanakan kegiatan usahanya secara konvensional maupun secara syariah.

\section{Upaya Preventif Perbankan}

Pada saat konsumen ingin memiliki kartu debit konsumen wajib memiliki rekening pada bank terkait, saat konsumen sepakat membuka rekening dengan bank terkait disitu terjadi suatu hubungan hukum. Dalam enghindari terjadinya kendala pada konsumen saat menggunakan kartu debit pihak bank berkewajiban untuk memberikan penjelasan secara tertulis kepada konsumen pengguna kartu debit. Hal ini diatur di dalam Pasal 23 Peraturan Bank Indonesia 14/2/PBI/ 2012 tentang Perubahan Atas Peraturan Bank Indonesia Nomor 11/11/PBI/ 2009 tentang Penyelenggaraan Kegiatan Alat Pembayaran Dengan Menggunakan Kartu bahwa

“Penerbit Kartu ATM dan/atau Kartu Debet wajib memberikan informasi secara tertulis kepada Pemegang Kartu, paling kurang meliputi:

a. prosedur dan tata cara penggunaan Kartu ATM dan/atau Kartu Debet, fasilitas yang melekat pada Kartu ATM dan/atau Kartu Debet, dan risiko 
yang mungkin timbul dari penggunaan Kartu ATM dan/atau Kartu Debet;

b. hak dan kewajiban Pemegang Kartu ATM dan/atau Kartu Debet; dan

c. tata cara pengajuan pengaduan permasalahan yang berkaitan dengan penggunaan Kartu ATM dan/atau Kartu Debet sebagaimana dimaksud pada huruf a dan lamanya waktu penanganan pengaduan tersebut."

Penjelasan tertulis oleh pihak bank merupakan wujud perlindungan konsumen dan masyarakat. Dari sisi perbankan upaya pencegahan yang dapat dilakukan bank terhadap merchant yaitu terdapat dalam Pasal 8 ayat 1 Peraturan Bank Indonesia 14/2/PBI/ 2012 tentang Perubahan Atas Peraturan Bank Indonesia Nomor 11/11/PBI/2009 tentang Penyelenggaraan Kegiatan Alat Pembayaran Dengan Menggunakan Kartu bahwa pihak bank wajib melakukan edukasi dan pembinaan terhadap pedagang yang bekerjasama dengan pihak bank. Edukasi dan pembinaan yang dilakukan bank kepada merchant saat merchant mengajukan mesin Electronic Data Captured (EDC) yaitu terdapat pada saat pengajuan.

Tujuan adanya upaya pencegahan yang dapat dilakukan Otoritas Jasa Keuangan (OJK) maupun perbankan adalah untuk meminimalisir adanya merchant yang melakukan pelanggaran dengan membebankan biaya tambahan agar tidak merugikan konsumen saat melakukan transaksi di mesin EDC menggunakan kartu debit.

\section{Perlindungan Hukum Bagi Konsumen Jika Dikenakan Biaya Tambahan Pada Mesin Electronic Data Captured (EDC)}

Jika terjadi sengketa antara konsumen dan pelaku usaha yang dapat merugikan para pihak yang bersengketa terdapat upaya hukum di dalam UndangUndang Nomor 8 Tahun 1999 tentang Perlindungan Konsumen yaitu terdapat dalam Pasal 45 sampai Pasal 48. Bahwa Undang-Undang Perlindungan Konsumen memberikan 2 (dua) alternatif penyelesaian sengketa yaitu:

- Penyelesaian Sengketa Di luar Pengadilan (Pasal 47)

- Penyelesaian Sengketa Melalui Pengadilan (Pasal 48) 
Menurut Pasal 45 ayat (2) Undang-Undang Nomor 8 Tahun 1999 tentang Perlindungan Konsumen bahwa konsumen pengguna kartu debit yang dirugikan oleh merchant dapat secara sukarela memilih menyelesaikan sengketa melalui pengadilan maupun di luar pengadilan.

\section{Penyelesaian Sengketa Di Luar Pengadilan (Non Litigasi)}

\section{a. Melalui Perbankan Terkait}

Penyelesaian sengketa konsumen pengguna kartu debit dapat dilakukan melalui jalur di luar pengadilan yaitu melalui pengaduan nasabah yang difasilitasi oleh pihak perbankan terkait. Pengaduan nasabah tersebut merupakan salah satu bentuk peningkatan perlindungan terhadap nasabah dalam rangka menjamin hak-hak nasabah dalam berhubungan baik dengan bank. ${ }^{15}$ Peraturan Otoritas Jasa Keuangan Nomor 1/POJK.07/2013 tentang Perlindungan Konsumen Sektor Jasa Keuangan yang memberikan perlindungan konsumen dengan menerapkan prinsip penanganan pengaduan serta penyelesaian sengketa konsumen secara sederhana, cepat, dan biaya terjangkau. Bank sebagai pihak yang menerbitkan kartu debit menurut Pasal 29 Peraturan Otoritas Jasa Keuangan Nomor 1/ POJK.07/2013 tentang Perlindungan Konsumen Sektor Jasa Keuangan wajib bertanggung jawab atas kerugian yang timbul akibat kesalahan dan/ atau kelalaian pihak ketiga yang bekerja untuk kepentingan pelaku usaha jasa keuangan, pihak ketiga sebagaimana dimaksud dalam pasal tersebut adalah merchant. Untuk mewujudkan prinsip penanganan pengaduan serta penyelesaian sengketa konsumen secara sederhana, cepat, dan biaya terjangkau terdapat peraturan Otoritas Jasa Keuangan mengenai layanan pengaduan konsumen di sektor jasa keuangan.

Terdapat Peraturan Otoritas Jasa Keuangan Nomor 18/POJK.07/2018 tentang Layanan Pengaduan Konsumen Di Sektor Jasa Keuangan dengan

15 Trinovita Krispabawni, 'Perlindungan Hukum Terhadap Nasabah Dalam Penyelesaian Sengketa Perbankan Melalui Lembaga Alternatif Penyelesaian Sengketa' (2018) 3 Badamai Law Jurnal.[285]. 
tujuan untuk mengupayakan penyelesaian pengaduan konsumen dalam rangka wujud perlindungan konsumen, layanan pengaduan wajib dimiliki oleh semua pelaku usaha jasa keuangan termasuk perbankan. Pengaduan dapat dilakukan secara lisan maupun tertulis.

b. Melalui Lembaga Alternatif Penyelesaian Sengketa (LAPS)

Pengertian Lembaga Altenatif Penyelesaian Sengketa selanjutnya disebut dengan LAPS menurut Pasal 1 angka 1 Peraturan Otoritas Jasa Keuangan Nomor 1/POJK.07/2014 tentang Lembaga Alternatif Penyelesaian Sengketa adalah lembaga yang melakukan penyelesaian sengketa di luar pengadilan. Ketika konsumen yang telah melakukan pengaduan kepada lembaga jasa keuangan tetapi tidak mencapai kesepakatan maka penyelesaian sengketa tersebut dapat dilakukan melalui LAPS yang telah terdaftar dalam Daftar Lembaga Alternatif Penyelesaian Sengketa yang ditetapkan oleh OJK. LAPS memiliki layanan penyelesaian sengketa yaitu mediasi, ajudikasi, dan arbitrase.

Di dalam sektor perbankan nama LAPS yang terdapat adalah Lembaga Alternatif Penyelesaian Sengketa Perbankan Indonesia (LAPSPI). Pembentukan LAPS di sektor perbankan di bentuk oleh beberapa bank yang dikoordinasi oleh asosisasi di sektor perbankan, misalnya Perhimpunan Bank Nasional (Perbanas), Himpunan Bank Milik Negara (Himbara), Perhimpunan Bank Perkreditan Rakyat Indonesia (Perbarindo), Asosiasi Bank Pembangunan Daerah (Asbanda), Asosiasi Bank Syariah Indonesia (Asbisindo), dan Asosiasi Bank Internasional (Asbi). ${ }^{16}$

LAPS memiliki skema layanan peneyelesaian sengketa yang mudah diakses konsumen, dan mengembangkan strategi komunikasi untuk meningkatkan akses konsumen terhadap layanan LAPS. ${ }^{17}$

16 Otoritas Jasa Keuangan, 'Lembaga Alternatif Penyelesaian Sengketa Acessed' <https:// www.ojk.go.id/id/kanal/edukasi-dan-perlindungan-konsumen/Pages/Lembaga-Alternatif-Penyelesaian-Sengketa.aspx>.

${ }^{17}$ Wetria Fauzi, 'Pengaturan Pengajuan Gugtan Oleh Otoritas Jasa Keuangan Dalam Penyelesaian Sengketa Asuransi Di Indonesia' (2019) 5 Jurnal Hukum Acara Perdata ADHAPER' (2019) 5 Jurnal Hukum Acara Perdata ADHAPER.[82]. 


\section{c. Melalui Badan Altenatif Penyelesaian Sengketa (BPSK)}

Badan Penyelesaian Sengketa Konsumen diatur pengertiannya dalam Pasal 1 angka 11 Undang-Undang Perlindungan Konsumen yaitu badan yang bertugas menangani dan menyelesaikan sengketa antara pelaku usaha dan konsumen. BPSK merupakan pengadilan khusus konsumen (small action court) yang diharapkan dapat menjawab tuntutan masyarakat agar proses berperkara berjalan cepat, sederhana, dan murah. ${ }^{18}$ Gugatan yang diajukan melalui BPSK merupakan gugatan secara perorangan, dengan demikian BPSK hanya menerima perkara yang nilai ganti kerugiannya relatif kecil. Pemeriksaan dilakukan oleh hakim tunggal dan kehadiran penuh pihak ketiga (pengacara) sebagai wakil pihak yang bersengketa tidak diperkenankan. ${ }^{19}$

\section{d. Melalui Gugatan Perwakilan Kelompok (Class Action)}

Undang-Undang Perlindungan Konsumen memberikan fasilitas mengajukan gugatan secara kelompok, gugatan tersebut dapat dilakukan oleh seorang konsumen yang dirugikan, kelompok konsumen yang memiliki kepentingan yang sama, lembaga perlindungan konsumen swadaya masyarakat yang berbentuk badan hukum atau yayasan, dan pemerintah atau instansi. Menurut penjelasan Pasal 46 ayat (1) huruf b bahwa "Undang-undang ini mengakui gugatan kelompok atau class action. Gugatan kelompok atau class action harus diajukan oleh konsumen yang benar-benar dirugikan dan dapat dibuktikan secara hukum, salah satu diantaranya adalah adanya bukti transaksi." Gugatan perwakilan kelompok diatur lebih lanjut di dalam Peraturan Mahkamah Agung Nomor 1 Tahun 2002 tentang Acara Gugatan Perwakilan Kelompok untuk selanjutnya disebut dengan PERMA 1/ 2002. Gugatan perwakilan kelompok merupakan gugatan dimana satu orang atau lebih yang memiliki kelompok mengajukan gugatan untuk dirinya sendiri atau mewakili

\footnotetext{
${ }^{18}$ Celina Tri Siwi Kristiyanti, Hukum Perlindungan Konsumen (Sinar Grafika 2008).[126].

19 ibid.
} 
sekelompok orang yang memiliki kesamaan fakta atau dasar hukum. Tujuan adanya gugatan class action adalah memudahkan akses masyarakat dalam memperoleh keadilan dan efisiensi penyelesaian sengketa yang merugikan banyak orang, namun kelemahan dari gugatan class action yaitu kesulitan dalam mengelola banyaknya jumlah anggota kelompok sehingga semakin sulit mengelola gugatan class action biasanya pada saat pembagian ganti kerugian sehingga dapat menyebabkan ketidakadilan. ${ }^{20}$

Dalam kasus ini yang paling tepat dilakukan oleh konsumen yang dirugikan akibat pembebanan biaya tambahan oleh merchant yaitu melalui layanan pengaduan nasabah yang difasilitasi oleh setiap bank, jika dalam hal ini gagal konsumen dapat menyelesaikan melalui Lembaga Alternatif Penyelesaian Sengketa Konsumen

\section{Sengketa Di Pengadilan (Litigasi)}

Undang-Undang Nomer 8 Tahun 1999 tentang Perlindungan Konsumen memfasilitasi untuk beracara di peradilan umum hal ini sesuai Pasal 45 Ayat (1) Undang-Undang Nomor 8 Tahun 1999 tentang Perlindungan Konsumen. Sama seperti sengketa perdata lainnya, sengketa konsumen di peradilan umum diawali dengan mengajukan gugatan oleh pihak yang dirugikan bisa pelaku usaha dan/atau konsumen. Menurut Pasal 23 Undang-Undang Perlindungan Konsumen bahwa sebelum konsumen mengajukan gugatan ke peradilan umum terlebih dahulu mengajukan tuntutan langsung kepada pelaku usaha, tuntutan tersebut berupa tuntutan ganti rugi menurut Pasal 19 Undang-Undang Perlindungan Konsumen jika pelaku usaha menolak tuntutan atau tidak meberi ganti kerugian kepada konsumen maka konsumen dapat mengajukan ke Badan Penyelesaian Sengketa Konsumen atau Peradilan dimana tempat konsumen berasal. Untuk perkara pembebanan biaya tambahan oleh merchant kepada konsumen pengguna kartu debit tidak di sarankan menggunakan jalur peradilan, dikarenakan nilai nominal yang dibebankan kepada konsumen 2007).[5].

${ }^{20}$ Emerson Yuntho, Class Action Sebuah Pengantar (Lembaga Studi Advokasi Masyarakat 
pengguna kartu debit relatif kecil sehingga kerugian yang diderita oleh konsumen pengguna kartu debit pun sedikit sesuai dengan nilai Merchant Discount Rate yang telah ditetapkan oleh masing-masing perbankan. Kerugian yang diperoleh konsumen pengguna kartu debit tidak sebanding dengan biaya perkara yang diberikan pengadilan kepada pihak yang bersengketa, umumnya biaya perkara di pengadilan bisa dibilang mahal.

\section{Kesimpulan}

Pembebanan biaya tambahan oleh merchant kepada konsumen menurut Pasal 8 Ayat (2) Peraturan Bank Indonesia Nomor 14/2/PBI/2012 tentang Perubahan Atas Peraturan Bank Indonesia Nomor 11/11/PBI/2009 tentang Penyelenggaraan Kegiatan Alat Pembayaran Dengan Menggunakan Kartu adalah tidak diperbolehkan. Sehingga terdapat pelanggaran hak konsumen yang dilanggar dalam Undang-Undang nomor 8 Tahun 1999 tentang Perlindungan Konsumen ketika merchant membebankan biaya tambahan kepada konsumen pengguna kartu debit. Hak konsumen yang dilanggar yaitu Pasal 4 huruf b, huruf c, huruf g dan huruf h.

Upaya hukum yang dapat dilakukan oleh konsumen pengguna kartu debit dapat dilakukan melalui jalur di luar pengadilan melalui pengaduan nasabah yang disediakan oleh setiap bank, jika gagal konsumen dapat mengajukan ke Lembaga Alternatif Penyelesaian Sengketa. Setiap pelaku usaha jasa keuangan wajib menyediakan layanan pengaduan konsumen yang bertujuan untuk memberikan perlindungan konsumen.

Pemerintah telah mengatur mengenai perlindungan terhadap konsumen dalam Undang-Undang Nomor 8 Tahun 1999 tentang Perlindungan Konsumen, serta peraturan-peraturan yang berasal dari Bank Indonesia, Otoritas Jasa Keuangan hal tersebut merupakan wujud dari perlindungan terhadap konsumen. Pentingnya kesadaran konsumen kartu debit untuk sadar akan haknya yang telah diatur dalam peraturan-peraturan tersebut walaupun jumlah kerugian yang diperoleh relatif kecil namun kesadaran konsumen tersebut penting agar konsumen 
tidak dirugikan terus menerus oleh merchant yaitu dengan cara konsumen dapat melakukan pengaduan ke layanan pengaduan nasabah yang telah disediakan oleh setiap bank.

Perlunya upaya pencegahan yang dilakukan pihak bank terhadap merchant yang memiliki mesin Electronic Data Captured (EDC) walaupun di dalam Peraturan Bank Indonesia telah diatur mengenai larangan membebankan biaya tambahan namun tidak terdapat sanksi secara jelas kepada pihak merchant yang melakukan pelanggaran. Bank selaku pihak yang melakukan perjanjian dengan merchant dapat memberikan sanksi kepada merchant yang melanggar perjanjian, serta pihak bank dapat melakukan kunjungan lapangan ke merchant. Pihak yang melakukan perjanjian penggunaan kartu debit yaitu bank dan konsumen, pihak yang melakukan perjanjian penggunaan mesin EDC (Electronic Data Captured) yaitu bank dan merchant dapat menambahkan klausula pada perjanjian dengan cara penyelesaian sengketa dengan mengajukan ke layanan pengaduan nasabah dan Lembaga Alternatif Penyelesaian Sengketa (LAPS).

\section{Daftar Bacaan}

\section{Buku}

Andi Sri Rezky Wulandari dan Nurdiyana Tadjuddin, Hukum Perlindungan Konsumen (Mitra Wacana Media 2019).

Bomantoro S, Implementasi Doktrin Penyalahgunaan Keadaan Dalam Perjanjian Dalam Praktek Peradilan Di Indonesia (Universitas Islam Indonesia 2004).

Celina Tri Siwi Kristiyanti, Hukum Perlindungan Konsumen (Sinar Grafika 2008).

Emerson Yuntho, Class Action Sebuah Pengantar (Lembaga Studi Advokasi Masyarakat 2007).

Kasmir, Bank Dan Lembaga Keuangan Lainnya (Rajawali Press 2001).

Shomad TPU dan A, Hukum Perbankan (Kencana 2017).

\section{Jurnal}

Agus Suwandono dan Deviana Yuanitasari, 'Kedudukan Lembaga Alternatif 
Penyelesaian Sengketa Sektor Jasa Keuangan Dalam Hukum Perlindungan Konsumen' (2016) 1 Bina Mulia Hukum.

Anand G, 'Prinsip Kebebasan Berkontrak Dalam Penyusunan Kontrak' [2011] Yuridika.

Fauzi W, 'Pengaturan Pengajuan Gugtan Oleh Otoritas Jasa Keuangan Dalam Penyelesaian Sengketa Asuransi Di Indonesia' (2019) 5 Jurnal Hukum Acara Perdata ADHAPER' (2019) 5 Jurnal Hukum Acara Perdata ADHAPER.

\section{Laman}

Otoritas Jasa Keuangan, 'Lembaga Alternatif Penyelesaian Sengketa Acessed' <https://www.ojk.go.id/id/kanal/edukasi-dan-perlindungankonsumen/Pages/Lembaga-Alternatif-Penyelesaian-Sengketa.aspx>

\section{Perundang-undangan}

Burgerlijk Wetboek (Kitab Undang-Undang Hukum Perdata).

Undang-Undang Nomor 8 Tahun 1999 tentang Perlindungan Konsumen (Lembaran Negara Republik Indonesia Tahun 2013 Nomor 118).

Undang-Undang Nomor 7 Tahun 1992 tentang Perbankan (Lembaran Negara Republik Indonesia Tahun 1992 Nomor 3 1, Tambahan Lembaran Negara Republik Indonesia Nomor 3472) sebagaimana telah diubah dengan Undang-Undang Nomor 10 Tahun 1998 tentang Perubahan atas UndangUndang Nomor 7 Tahun 1992 tentang Perbankan (Lembaran Negara Republik Indonesia Tahun 1998 Nomor 182, Tambahan Lembaran Negara Republik Indonesia Nomor 3790).

Undang-Undang Nomor 21 Tahun 2011 tentang Otoritas Jasa Keuangan (Lembaran Negara Republik Indones Tahun 2011 Nomor 111, Tambahan Lembaran Negara Republik Indonesia Nomor 5253).

Peraturan Mahkamah Agung Nomor 1 Tahun 2002 tentang Acara Gugatan Perwakilan Kelompok.

Peraturan Bank Indonesia Nomor 7/7/PBI/ 2005 tentang Penyelesaian Pengaduan Nasabah (Lembaran Negara Republik Indonesia Tahun 2005 Nomor 17 DPNP/DPbS/DPBPR, Tambahan Lembaran Negara Republik Indonesia Nomor 4476).

Peraturan Bank Indonesia Nomor 14/02/PBI/2012 tentang Perubahan Atas Peraturan Bank Indonesia Nomor 11/11/PBI/2009Tentang Penyelenggaraan 
Kegiatan Alat Pembayaran Dengan Menggunakan Kartu (Lembaran Negara Republik Indonesia Tahun 2012 Nomor 11, Tambahan Lembaga Negara Republik Indonesia Nomor 6081).

Peraturan Otoritas Jasa Keuangan Nomor 1/POJK.07/2013 tentang Perlindungan Konsumen Sektor Jasa Keuangan (Lembaran Negara Republik Indonesia Tahun 2013 Nomor 118).

Peraturan Otoritas Jasa Keuangan Nomor 1/POJK.07/2014 tentang Lembaga Alternatif Penyelesaian Sengketa Di Sektor Jasa Keuangan (Lembaran Negara Republik Indonesia Tahun 2014 Nomor 12, Tambahan Lembaran Negara Republik Indonesia Nomor 5499).

Peraturan Otoritas Jasa Keuangan Nomor 18/POJK.07/2018 tentang Layanan Pengaduan Konsumen Di Sektor Jasa Keuangan (Lembaran Negara Republik Indonesia Tahun 2018 Nomor 151, Tambahan Lembaran Negara Republik Indonesia Nomor 6246).

How to cite: Lana Almira Luthfiana Istiqlal dan Dian Purnama Anugerah, ‘Perlindungan Hukum Bagi Konsumen Pengguna Kartu Debit Terkait Pembebanan Biaya Tambahan Pada Mesin EDC (Electronic Data Captured)' (2020) Vol. 3 No. 1 Media Iuris. 